\title{
INVESTMENT BANKING AND THE CAPITAL ACQUISITION PROCESS
}

\author{
Clifford W. SMITH, Jr.* \\ University of Rochester, Rochester, NY 14627, USA
}

Received March 1985, final version received August 1985

\begin{abstract}
This paper reviews the theory and evidence on the process by which sorporations raise debt and equity capital and the associated effects on security prices. Findings from related transactions are used to test hypotheses about the stock pricc patterns accompanying announcements of security offerings. Various contractual alternatives employed in security issues are examined; for example, rights or underwritten offers, negotiated or competitive bid, best efforts or firm commitment contracts, and shelf or traditional registration. Finally, incentives for underpricing new issues are analyzed.
\end{abstract}

\section{Introduction}

Corporations raise external capital by selling a range of different securities which they market in a variety of different ways. The Dealers' Digest (1985) reports that $\$ 355.3$ billion in public securities sales have been underwritten between 1980 and 1984 . Of that total value, 24 percent is common stock, 5 percent is preferred stock, 2 percent is convertible preferred stock, 63 percent is debt, and 6 percent is convertible debt. Contracts negotiated between the issuing firm and underwriter comprise 95 percent of the offers, while in 5 percent the underwriter is selected through a competitive bid. Shelf registration accounts for 27 percent of the issues, while 73 percent are registered employing traditional procedures.

Capital markets play an important role in the theory of corporate financial economics; for example, capital market prices provide vital signals for corporate investment decisions. Yet we do not have a detailed understanding of the various contractual arrangements in the process of raising capital, or of the influence of this process on corporate financial and investment policy.

\footnotetext{
*I would like to thank Armen Alchian and the participants at the MERC Conference on Investment Banking and the Capital Acquisition Process, especially H. DeAngelo, M. Jensen, D. Mayers, R. Masulis, W. Schwert, R. Stulz and J. Warner for their comments. This research was supported by the Managerial Economics Research Center, Graduate School of Management, University of Rochester.
} 
Section 2 examines the theory and evidence related to announcements of security offerings by public corporations. Average stock price reactions to public security issues are either negative or not significantly different from zero. Several hypotheses have been offered to explain these price reactions. The hypotheses also have implications for price reactions in related events, such as dividend changes and security repurchases. It is therefore possible to evaluate their relative merit by drawing on existing evidence about price reactions to these related announcements.

Section 3 examines the marketing of corporate securities. Securities can be sold through either a rights or an underwritten offering. Underwriters' services can be obtained through either a negotiated or a competitive bid contract. Finally, the securities can be registered with the Securities and Exchange Commission (SEC) through either the new shelf or traditional registration procedures. Data on the costs, pricing, and frequency of use of these marketing methods for different sccurities provide a clearer understanding of the incentives important in choosing among them.

Section 4 examines the special case of initial public equity offerings. They are typically sold through either firm commitment or best effort contracts. Underwriters, on average, price initial public offerings significantly lower than their after-market price. The hypotheses which explain these choices are examined.

Section 5 presents brief concluding remarks, and suggests issues for further study.

\section{On the corporation's choice of security to offer}

A public corporation seeking external capital must first decide what type of claim to sell. In choosing the type of security to issue, it is important to understand the market reaction to the announcement. Table 1 summarizes two-day common stock price reactions adjusted for general market price changes (abnormal returns) to announcements of public issues of common stock, preferred stock, convertible preferred stock, straight debt and convertible debt by industrial and utility firms. Four generalizations about relative magnitudes are suggested in table 1: (1) the average abnormal returns are non-positive; (2) abnormal returns associated with announcements of common stock sales are negative and larger in absolute value than those observed with preferred stock or debt; (3) abnormal returns associated with announcements of convertible securities are negative and larger in absolute value than those for corresponding non-convertible securities; and (4) abnormal returns associated with sales of securities by industrials are negative and larger in absolute value than those for utilities.

There are several hypotheses for this pattern of relative stock price effects: (1) Optimal Capital Structure - firms have an optimal capital structure and 


\section{Table 1}

Average two-day abnormal common stock returns and average sample size (in parentheses) from studies of announcements of security offerings. Returns are weighted averages by sample size of the returns reported by the respective studies (unless noted otherwise, returns are significantly different from zero).

\begin{tabular}{lcc}
\hline & \multicolumn{2}{c}{ Type of issuer } \\
\cline { 2 - 3 } Type of security offering & Industrial & Utility \\
\hline Common stock & $-3.14^{\mathrm{a}}$ & $-0.75^{\mathrm{b}}$ \\
Preferred stock & $(155)$ & $(403)$ \\
Convertible preferred stock & $-0.19^{\mathrm{c} . *}$ & $+0.08^{\mathrm{d} . *}$ \\
Straight bonds & $(28)$ & $(249)$ \\
& $-1.44^{\mathrm{d}}$ & $-1.38^{\mathrm{d}}$ \\
Convertible bonds & $(53)$ & $(8)$ \\
& $-0.26^{\mathrm{e}, *}$ & $-0.13^{\mathrm{f} . *}$ \\
\end{tabular}

"Source: Asquith and Mullins (1986), Kolodny and Suhler (1985), Masulis and Korwar (1986), Mikkelson and Partch (1986), Schipper and Smith (1986).

${ }^{b}$ Source: Asquith and Mullins (1986). Masulis and Korwar (1986), Pettway and Radcliffe (1985)

'Source: Linn and Pinegar (1985), Mikkelson and Partch (1986).

${ }^{d}$ Source: Linn and Pinegar (1985).

'Source: Dann and Mikkelson (1984), Eckbo (1986), Mikkelson and Partch (1986).

${ }^{\text {t}}$ Source: Eckbo (1986).

${ }^{8}$ Not available (virtually none are issued by utilities).

${ }^{*}$ Interpreted by the authors as not statistically significantly different from zero.

these price reactions reflect the change in the value of the firm associated with the adjustment of the firm's liability structure; (2) Implied Cash Flow Change - the stock price changes provide information about future expected net operating cash flows; (3) Unanticipated Announcements - stock price changes reflect only the unanticipated component of the announcement, hence the more predictable an event, the smaller the associated stock price change; (4) Information Asymmetry - corporate managers have more information than the marginal purchaser of securities, hence corporate managers are more likely to issue securities when they are overpriced in the market; (5) Ownership Changes - transactions that change the distribution of control rights in the firm affect the value of the firm's shares. These hypotheses are examined to identify the extent to which each helps explain the price effects in table 1. The hypotheses are not mutually exclusive. Ilowever, each hypothesis also has implications for price reactions to related announcements. Augmenting the observations in table 1 with empirical evidence from the analysis of other events helps identify relative orders of importance. 


\subsection{Optimal capital structure and relative price effects}

With fixed investment policy and no contracting costs or taxes, the value of the firm is independent of the structure of its liabilities [Modigliani and Miller (1958)]. This capital structure irrelevance hypothesis implies that the function relating leverage and the value of the firm is a horizontal line. Alternatively, if taxes or contracting costs are important, or if investment policy and capital structure are interdependent, then the market value of the firm depends on the structure of its liabilities. In the case of the capital structure relevance hypothesis, the function relating firm value and leverage is concave. ${ }^{1}$ But neither hypothesis by itself provides a satisfactory explanation of the estimates in table 1. Maximizing behavior by firms implies that in voluntary transactions such as security sales, the firm should structure the transaction to yield the highest possible value of the firm. Thus, if a transaction moves a company along a given leverage-value function, the irrelevance hypothesis implies there should be no abnormal returns associated with announcements of security sales, while the capital structure relevance hypothesis implies the abnormal returns should be non-negative. Therefore, the negative returns in table 1 are inconsistent with both predictions.

Reductions in firm value associated with apparently voluntary security sales present a puzzle. It is possible that security sales are optimal responses to an adverse change in the firm's prospects, and the negative price reaction is due to the revelation of the adverse change. Even if a security sale might itself increase the value of the firm, it could lead potential securityholders to believe the firm has received bad news. Of course, if the announcement of the transaction is also associated with a shift in the leverage-value function, then the theory has no implication for the magnitudes observed in table 1 . Without a theory capable of differentiating between movement along a given leveragevalue function and a shift in the function, it is difficult to test hypotheses about optimal capital structure by looking at the stock price reactions to announcements of security sales. Therefore, at the current stage of development, studies of financing decisions provide relatively weak tests of optimal capital structure theories.

\subsection{Implied changes in expected net operating cash flow and relative price effects}

The firm's cash-flow identity states that sources must equal uses of funds. Therefore, an announcement of a new security sale must be matched either by an increase in new investment expenditure, a reduction in some liability (such

\footnotetext{
${ }^{1}$ Various analyses emphasize different characteristics of claims such as corporate taxes [Modigliani and Miller (1962), Brennan and Schwartz (1978)], personal taxes [DeAngelo and Masulis (1980)], transactions costs of bankruptcy [Kraus and Litzenberger (1973)] and agency costs [Jensen and Meckling (1976), Myers (1977), Smith and Warner (1979)].
} 
as debt retirement or share repurchase), an increased dividend or a reduction in expected net operating cash flow. In the Miller and Rock (1985) analysis of dividends, they hypothesize that investors draw inferences about implied changes in expected net operating cash flows from corporate dividend announcements. They suggest that larger-than-expected dividend payments are associated with larger-than-expected internally generated cash flows from operations, and thus the dividend increase represents good news for investors. The evidence in table 1 is generally consistent with this hypothesis if the hypothesis is modified to consider security sales, so that unexpected security sales are associated with smaller-than-expected cash flows from operations, and thus security sales represent bad news for investors.

This argument can be generalized to consider other announcements which do not explicitly link sources and uses of funds. In general, to predict the implied change in cash flow, everything except net operating cash flow and the announcement policy variable is held fixed. Thus, announcements of security repurchases, increases in investment expenditures or higher dividend payments are associated with implied increases in expected cash flow; and security offerings, reductions in investment expenditures or lower dividend payments are associated with implied reductions in expected cash flow. If there is an implied increase in the corporation's expected net operating cash flow, the value of the firm should rise and there should be a corresponding increase in the value of the firm's equity.

Table 2 summarizes the evidence from studies of announcements of sales of new securities, stock repurchases, dividend changes and changes in investment policy grouped by their effect on implied changes in expected cash flows. The evidence of generally positive abnormal returns in the upper panel of table 2 associated with implied increases in cash flows, and generally negative abnormal returns in the lower panel associated with implied decreases in cash flows, is consistent with the hypothesis that security market participants draw inferences about changes in operating cash flow from announcements that do not explicitly associate sources with uses of funds.

The hypothesis that investors infer changes in net operating cash flows from investment, financing, and dividend policy announcements predicts nonpositive price reactions to announcements of security sales. However, this hypothesis does not predict differential reactions to debt versus equity sales, convertible versus non-convertible issues or sales by industrial versus utility firms.

\subsection{Unanticipated announcements and relative price effects}

Because stock price changes reflect only the unanticipated component of the announcement, the magnitude of the stock price change at the announcement will vary inversely with the degree of predictability of the announcement if 
Table 2

Average two-day common stock abnormal returns and average sample size from studies of changes in financing, dividend, and investment policy, grouped by implied changes in expected corporate cash flows. Returns are weighted averages by sample size of the returns reported by the respective studies (unless otherwise noted, returns are significantly different from zero).

\begin{tabular}{|c|c|c|}
\hline Type of announcement & $\begin{array}{l}\text { Average } \\
\text { sample } \\
\text { size }\end{array}$ & $\begin{array}{l}\text { Two-day } \\
\text { announcement } \\
\text { period return }\end{array}$ \\
\hline \multicolumn{3}{|c|}{ Implied increase in expected corporate cash flow } \\
\hline $\begin{array}{l}\text { Common stock repurchases } \\
\text { intra-firm tender offer }^{\mathrm{a}} \\
\text { open market repurchase } \\
\text { targeted small holding }^{\mathrm{b}}\end{array}$ & $\begin{array}{r}148 \\
182 \\
15\end{array}$ & $\begin{array}{l}16.2 \% \\
3.6 \\
1.6\end{array}$ \\
\hline Calls of non-convertible bonds ${ }^{d}$ & 133 & $-0.1^{*}$ \\
\hline $\begin{array}{l}\text { Dividend increases } \\
\text { dividend initiation } \\
\text { dividend increase }^{\mathrm{f}} \\
\text { specially designated dividend }\end{array}$ & $\begin{array}{l}160 \\
280 \\
164\end{array}$ & $\begin{array}{l}3.7 \\
0.9 \\
2.1\end{array}$ \\
\hline Investment increases ${ }^{h}$ & 510 & 1.0 \\
\hline \multicolumn{3}{|c|}{ Implied decrease in expected corporate cash flow } \\
\hline $\begin{array}{l}\text { Security sales } \\
\text { common stock }^{i} \\
\text { preferred stock }^{j} \\
\text { convertible preferred } \\
\text { straight debt } \\
\text { convertible debt }^{1}\end{array}$ & $\begin{array}{r}262 \\
102 \\
30 \\
221 \\
80\end{array}$ & 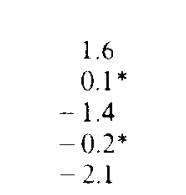 \\
\hline Dividend decreases ${ }^{f}$ & 48 & -3.6 \\
\hline Investment decreases ${ }^{h}$ & 111 & -1.1 \\
\hline
\end{tabular}

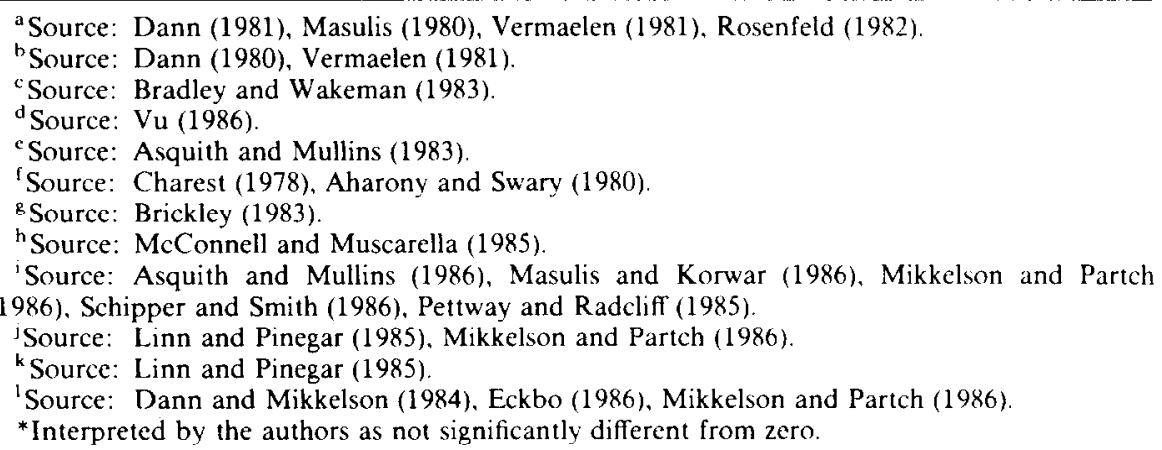


other effects are held constant. The evidence in tables 1 and 2 appears consistent with this hypothesis.

Predictability of debt versus equity offers. Expected growth in assets or expected debt repayment (either from maturing issues or sinking-fund provisions) require the firm to issue additional debt to maintain its capital structure. ${ }^{2}$ Given a target capital structure and unchanged cash flows, debt repayment must be matched with new debt issuance. The more predictable are principal repayments, the more predictable are new debt issues. Similarly, the predictability of earnings (and thus internally generated equity) will determine the predictability of the new externally obtained equity funds. In general, a new debt issue is likely to be more predictable than a new equity issue becausc principal repayments are more predictable than earnings.

Another reason for the greater predictability of public debt offerings is related to the cost structures of public versus private debt. Flotation costs for publicly placed debt have a larger fixed component and more pronounced economies of scale than bank debt. Thus, a firm will tend to use bank lines of credit until an efficient public issue size is reached, then the firm will issue public debt and retire the bank debt. If potential security holders can observe the amount of bank borrowing and the pattern of public debt issuance. then predictable announcements of public bond issues should have smaller price reactions [see Marsh (1982) for evidence on the use of short-term debt to predict public debt issues].

Predictability of industrial versus utility offers. Table 1 shows significant differences between the price reactions of industrials and utilities to new equity sales. Utilities appear to employ external capital markets more extensively than do industrials. If the higher frequency of use by utilities is associated with greater predictability of security issuance, then utilities should show a smaller observed stock price reaction to announcements of new security sales. But that raises the question of why the reliance on external capital markets differs between industrials and utilities.

A policy of paying larger dividends increases the frequency with which the corporation must go to the capital markets to raise new equity [Rozeff (1982) and Easterbrook (1984)]. If, when new funds are raised, the capital market provides effective monitoring of the firm's activities, then such a policy disciplines the firm more frequently and lowers agency costs. Firms with high investment rates and high demands for new capital frequently use capital markets anyway; for them the additional benefits of increased monitoring from

\footnotetext{
${ }^{2}$ Note that the economies of scale documented in the schedule of flotation costs generally make it optimal to make discrete rather than continuous leverage adjustments. For simplicity we ignore those flotation cost issues at present.
} 
higher dividends would be small. But utilities historically have both high demands for new capital and high dividend payout rates. I hypothesize that if the dividend rate is lowered and the frequency of selling new equity in capital markets is reduced, utility stockholders are likely to be damaged in the rate regulation process. By paying high dividends, the regulated firm subjects both its regulatory body as well as itself to capital market discipline more frequently. Stockholders are less likely to receive lower-than-normal levels of compensation due to lower allowed product prices when the regulatory authority is more frequently and effectively monitored by capital markets. Therefore, high dividends are a method of assuring a regulated firm's stockholders that they will receive a normal rate of return on the invested capital. This policy of high dividends also implies that the external security issuance by utilities is more predictable than for non-utilities. The smaller abnormal stock price changes for utilities than industrials is consistent with this hypothesis. ${ }^{3}$

Hypotheses about the predictability of announcements help explain the observed difference in announcement returns of common stock versus debt issues and industrials' versus utilities' offerings. ${ }^{4}$ However, these hypotheses apparently do not explain differences in announcement returns between common and preferred stock or between convertible and non-convertible issues.

\subsection{Information asymmetry and relative price effects}

Suppose that a potential purchaser of securities has less information than corporate managers, and corporate managers are more likely to issue securities when the market price of the firm's traded securities is higher than management's assessment of their value. This implies that the stock price effects of security issues will be greater the more the asymmetry in information between insiders and other security market participants [see Myers and Majluf (1984) and Myers (1984)]. Since debt and preferred stock are more senior claims, their values are less sensitive to changes in firm value than is common stock, and thus the information asymmetry problem is less severe. Similarly, convertible debt and convertible preferred stock are more sensitive to changes in firm value than non-convertible debt and preferred, but less so than common stock. Finally, in the rate regulation process, managers of utilities generally petition their respective regulatory authorities for permission for new security sales.

\footnotetext{
${ }^{3}$ Citizens Utilities is an apparent counter example to this hypothesis. Because of its special tax status, it is allowed no new equity issues, and perhaps for that reason has a very low payout ratio. It also has an AAA debt rating and the highest rate of return to stockholders among all utilities, and it appears to have the best record in rate regulation proceedings. See also Long (1978).

${ }^{4} \mathrm{Also}$, the evidence in table 2 of increases in dividends is consistent with this hypothesis. Dividend initiations are expected to have a larger unanticipated component than the ordinary dividend increases.
} 
This petitioning process could reducc the price reaction of utilities' announcements relative to industrials for any of three reasons: (1) it could reduce the differential information between manager and outsiders; (2) it could limit managers' discretion as to what security to sell; and (3) it could reduce managers' ability to time security offerings to take advantage of any differential information.

Thus, while the information asymmetry hypothesis does not predict the direction of announcement returns for debt or preferred issues, it offers a potential explanation of greater price changes associated with common stock than preferred or debt, for convertible than non-convertible issues, and for industrials than utilities.

While the evidence across classes of securities is consistent with the information asymmetry hypothesis, some data within security classes is apparently inconsistent. When Eckbo (1986) and Mikkelson and Partch (1986) disaggregate their bond data by rating class, neither study finds higher rated, less risky (and thus less sensitive to firm value) bonds to be associated with smaller abnormal returns. Eckbo also finds more negative abnormal returns to mortgage bonds than non-mortgage bonds. ${ }^{5}$

The information asymmetry hypothesis can be distinguished from hypotheses about implied cash flow changes by examining evidence from events that explicitly associate sources and uses of funds. Just as the information asymmetry hypothesis implies no obvious predictions about dividend or investment accouncements, the analysis of implied changes in net operating cash flows makes no prediction about the market reaction to announcements of exchange offers. The evidence in table 3 from exchange offers, conversion-forcing calls of convertible securities, and security sales where the proceeds are used for debt retirement suggests that: (1) the sign of the abnormal return and the sign of the leverage change are the same, and (2) the larger the change in leverage, the greater is the absolute value of the abnormal price reaction. Thus, debt-forcommon offers have larger stock price reactions than preferred-for-common offers, and common-for-debt offers have larger negative price reactions than common-for-preferred offers.

Combining the information asymmetry hypothesis and the hypothesis on implied changes in net operating cash flows provides additional insight into the difference between reported announcement effects of debt and equity. For example, in the upper panel of table 2, announcements of calls of non-convertible debt are associated with implied increases in expected net operating cash flow but yield an insignificant negative return. However, this event is also on average associated with a reduction in leverage. When $\mathrm{Vu}$ (1986) disaggregates his sample of calls of bonds by change in leverage, he finds that for the 72

\footnotetext{
${ }^{5}$ As Stulz and Johnson (1985) argue. secured debt should be less sensitive to firm value than non-secured debt.
} 
Table 3

Summary of two-day announcement effects associated with exchange offers, security sales with designated uses of funds, and calls of convertible securities. With sources and uses of funds associated, these transactions represent virtually pure financial structure changes.

\begin{tabular}{|c|c|c|c|c|}
\hline Type of transaction & $\begin{array}{l}\text { Security } \\
\text { issued }\end{array}$ & $\begin{array}{l}\text { Security } \\
\text { retired }\end{array}$ & $\begin{array}{l}\text { Average } \\
\text { sample } \\
\text { size }\end{array}$ & $\begin{array}{c}\text { Two-day } \\
\text { announcement } \\
\text { period return }\end{array}$ \\
\hline \multicolumn{5}{|l|}{$\begin{array}{l}\text { Leverage-increasing } \\
\text { transactions }\end{array}$} \\
\hline Stock repurchase ${ }^{a}$ & Debt & Common & 45 & $21.9 \%$ \\
\hline Exchange offer ${ }^{b}$ & Debt & Common & 52 & 14.0 \\
\hline Exchange offer ${ }^{b}$ & Preferred & Common & 9 & 8.3 \\
\hline Exchange offer ${ }^{b}$ & Debt & Preferred & 24 & 2.2 \\
\hline Exchange offer ${ }^{c}$ & Income bonds & Preferred & 24 & 2.2 \\
\hline \multicolumn{5}{|l|}{$\begin{array}{l}\text { Transactions with no } \\
\text { change in leverage }\end{array}$} \\
\hline Exchange offer $^{d}$ & Debt & Debt & 36 & $0.6^{*}$ \\
\hline Security sale ${ }^{f}$ & Debt & Debt & 83 & $0.2^{*}$ \\
\hline \multicolumn{5}{|l|}{$\begin{array}{l}\text { Leverage-reducing } \\
\text { transactions }\end{array}$} \\
\hline Conversion-forcing call ${ }^{\mathrm{e}}$ & Common & Convertible preferred & 57 & $-0.4^{*}$ \\
\hline Conversion-forcing call ${ }^{\mathrm{e}}$ & Common & Convertible bond & 113 & -2.1 \\
\hline Security sale ${ }^{f}$ & Convertible debt & Debt & 15 & -2.4 \\
\hline Exchange offer ${ }^{b}$ & Common & Preferred & 30 & -2.6 \\
\hline Exchange offer ${ }^{b}$ & Preferred & Debt & 9 & -7.7 \\
\hline Security sale ${ }^{f}$ & Common & Debt & 12 & -4.2 \\
\hline Exchange offer ${ }^{b}$ & Common & Debt & 20 & -9.9 \\
\hline
\end{tabular}

${ }^{a}$ Source: Masulis (1980).

bource: Masulis (1983). Note: These returns include announcement days of both the originat offer and for about 40 percent of the sample, a second announcement of specific terms of the exchange.

"Source: McConnell and Schlarbaum (1981).

${ }^{\mathrm{d}}$ Source: Dietrich (1984).

'Source: Mikkelson (1981).

'Source: Eckbo (1986), Mikkelson and Partch (1986).

* Not statistically different from zero.

firms that decrease leverage, there are significant stock price announcement returns of -1.1 percent; for the 30 firms with no change in leverage, +0.3 percent; and for the 31 firms that increase leverage, +0.9 percent.

\subsection{Changes in ownership and relative price effects}

In some transactions, part of the observed price reaction reflects important changes in the ownership and control of the firm. Table 4 summarizes the results from studies of transactions with potentially important control implications. The upper panel summarizes results of transactions where the organi- 


\section{Table 4}

Summary of cumulative abnormal common stock returns and average sample size from studies of announcements of transactions which change corporate control or ownership structure. Returns are weighted averages by sample size of the returns reported by the respective studies (unless otherwise noted, results are significantly different from zero).

\begin{tabular}{|c|c|c|}
\hline Type of announcement & $\begin{array}{l}\text { Average } \\
\text { sample } \\
\text { size }\end{array}$ & $\begin{array}{c}\text { Cumulative } \\
\text { abnormal } \\
\text { returns }\end{array}$ \\
\hline \multicolumn{3}{|l|}{ Organizational restructuring } \\
\hline $\begin{array}{r}\text { Merger: Target } \\
\text { Bidder }\end{array}$ & $\begin{array}{l}113 \\
119\end{array}$ & $\begin{array}{c}20.0 \% \\
0.7^{*}\end{array}$ \\
\hline Spin-off & 76 & 3.4 \\
\hline Sell-off: Seller ${ }^{\circ}$ & 279 & 0.7 \\
\hline Buyer ${ }^{d}$ & 118 & 0.7 \\
\hline Equity carve-out ${ }^{e}$ & 76 & $0.7^{*}$ \\
\hline Joint venture & 136 & 0.7 \\
\hline Going private $\mathrm{g}$ & 81 & 30.0 \\
\hline Voluntary liquidation ${ }^{h}$ & 75 & 33.4 \\
\hline Life insurance company mutualization & 30 & 56.0 \\
\hline Savings \& Loan $\wedge$ ssociation charter conversion ${ }^{i}$ & 78 & 5.6 \\
\hline Proxy fight ${ }^{k}$ & 56 & 1.1 \\
\hline \multicolumn{3}{|l|}{ Ownership restructuring } \\
\hline Tender offer: Target' & 183 & 30.0 \\
\hline Bidder $^{1}$ & 183 & $0.8^{*}$ \\
\hline Large block acquisition ${ }^{m}$ & 165 & 2.6 \\
\hline Secondary distribution: Registered $^{\mathrm{n}}$ & 146 & -2.9 \\
\hline Non-registered ${ }^{n}$ & 321 & -0.8 \\
\hline Targeted share repurchase ${ }^{\circ}$ & 68 & -4.8 \\
\hline
\end{tabular}

${ }^{a}$ Source: Dodd (1980), Asquith (1983), Eckbo (1983), Jensen and Ruback (1983).

'Source: Hite and Owers (1983), Miles and Rosenfeld (1983), Schipper and Smith (1983), Rosenfeld (1984).

'Source: Alexander, Benson and Kampmeyer (1984), Rosenfeld (1984), Hite and Owers (1985), Jain (1985), Klein (1985), Vetsuypens (1985).

${ }^{\mathrm{d}}$ Source: Rosenfeld (1984), Hite and Owers (1985), Jain (1985), Klein (1985).

'Source: Schipper and Smith (1986).

'Source: McConnell and Nantell (1985).

'Source: DeAngelo, DeAngelo and Rice (1984).

${ }^{\mathrm{h}}$ Source: Kim and Schatzberg (1985).

'Source: Mayers and Smith (1985).

'Source: Masulis (1985).

kSource: Dodd and Warner (1983).

'Source: Bradley, Desai and Kim (1985), Jensen and Ruback (1983).

m Source: Holderness and Sheehan (1985), Mikkelson and Ruback (1985).

"Source: Mikkelson and Partch (1985).

-Source: Dann and DeAngelo (1983), Bradley and Wakeman (1983).

*Interpreted by authors as not significantly different from zero. 
zation is restructured. The evidence suggests that organizational restructuring on average benefits stockholders. In the lower panel, value effects associated with a change in the distribution of ownership are examined. The evidence suggests that announcements of transactions that increase ownership concentration raise share prices, while those that reduce concentration lower share prices.

Organizational restructuring is sometimes accompanied by a security offering. For example, Schipper and Smith (1986) examine firms that sell common stock of a previously wholly owned subsidiary. In contrast to the negative returns from the sale of corporate common stock reported in table 1 , these 'equity carve-outs' are associated with significant positive returns of 1.8 percent for the five days around the announcement. ${ }^{6}$ There are important control implications of the public sale of a minority interest in a subsidiary. For example, management of the subsidiary can have a market-based compensation package that more accurately reflects subsidiary performance [see Smith and Watts $(1982,1984)]$. Schipper and Smith document that 94 percent of the carve-outs adopted incentive compensation plans based on the subsidiary's stock. The evidence from equity carve-outs is also consistent with the information asymmetry hypothesis. If management expects that the subsidiary is undervalued, then by segregating the subsidiary's cash flows and selling separate equity claims, the firm can more effectively capture that gain.

Some security sales involve potentially important ownership structure changes. For example, Masulis and Korwar (1986) isolate 56 offerings (not in table 4) for which, in addition to the primary equity issue, there is also a registered secondary offering by the firm's management. The two-day announcement period return for the offers is -4.5 percent, compared to -3.1 percent for the average industrial equity offering.

\section{Security offerings by public corporations}

After a firm decides on the security to issue, it must choose among a number of methods to market it. The firm can offer the securities on a pro rata basis to its own stockholders through a rights offering; it can hire an underwriter to offer the securities for sale to the public; or it can place the securities privately. If the firm uses an underwriter, ${ }^{7}$ it can negotiate the offering terms with the underwriter, or it can structure the offering internally, then put it out for

\footnotetext{
${ }^{6}$ These positive returns are observed in spite of potentially large costs associated with these transactions. For example, the required information disclosures about the subsidiary are increased and the nature of the transactions that can take place between the parent and the subsidiary (to avoid potential conflict of interests between the parent's and subsidiary's outside stockholders) are restricted.

${ }^{7}$ Without exception, the analysis summarized here assumes effective competition within the investment banking industry. In fact, there are no effective barriers to entry in the industry. Effective competition provides strong incentives to supply efficient combinations of contractual provisions including services, fees, and underpricing.
} 
competitive bid. The underwriting contract can be a firm commitment or a best efforts offering. Finally, the issue can be registered with the Securities and Exchange Commission under its traditional registration procedures, or, if the firm qualifies, it can file a shelf registration in which the firm registers all securities it intends to sell over the next two years.

\subsection{Rights versus underwritten offerings}

The two most frequently employed methods by which public corporations market new securities are rights offerings and firm commitment underwritten offerings. In an underwritten offering, initial negotiation focuses on the amount of capital, the type of security, and the terms of the offering. If the firm and underwriter agree to proceed, the underwriter begins to assess the prospects. The investigation includes an audit by a public accounting firm and a legal opinion from a law firm. The issuing firm, the investment banker, the auditing firm and the law firm all typically participate in filing the required registration statements with the Securities and Exchange Commission (as well as with the appropriate state securities commissions). The offering can only proceed when the registration statement becomes effective. Although oral sales efforts are permitted, any indications of interest are not legally enforceable commitments of customers. No written sales literature other than a 'red herring' prospectus and 'tombstone advertisements' are permitted between the filing and offer datc. The 'Rules of Fair Practice' of the National Association of Sccurity Dealers require that once the underwriters file the offer price with the SEC, the securities cannot be sold above this price, although they can be offered at a lower price if the syndicate 'breaks'.

In a rights offering, each stockholder receives options to buy newly issued securities. One right is issued for each share held. The contract states the number of rights required to purchase one unit of the newly issued security, the exercise price, and the expiration date. Rights offerings must be registered with the SEC. Rights typically trade on the exchange on which the stock is listed.

Smith (1977) documents that the out-of-pocket expenses of an equity issue underwritten by an investment banker are from three to thirty times higher than the costs of a non-underwritten rights offering. Yet over 80 percent of the equity offerings he examines employ underwriters. ${ }^{8}$ Eckbo (1986) finds five percent of bond issues between 1964 and 1981 are sold through rights offers.

A number of authors have argued that investment bankers are effective in monitoring the firm's activities. ${ }^{9}$ The monitoring is potentially valuable be-

\footnotetext{
${ }^{*}$ Hansen and Pinkerton (1982) document that firms which employ rights offerings have high ownership concentrations. Although they claim to resolve the paradox about the use of rights offerings, they ignore all costs except direct costs reported to the SEC and, as Smith and Dhatt (1984) indicate, overstate the significance of their statistical tests.

${ }^{9}$ See Rozeff (1982), Easterbrook (1984), Booth and Smith (1986), Heinkel and Schwartz (1985), and Schneller (1985).
} 
cause of the differential information between managers and outside stockholders. Thus, in addition to a marketing function, the investment banker performs a monitoring function analogous to that of bond rating agencies [Wakeman (1981), Fama and Jensen (1985)], of independent auditing firms [Jensen and Meckling (1976), Watts (1977), DeAngelo (1981)], ${ }^{10}$ of outside members of a firm's board of directors [Fama (1980)], and of insurance companies [Mayers and Smith (1982)]. In each case, it is argued that while the activity is expensive, it is justified because periodic exposure of the firm's decision makers to effective monitoring raises the price external securityholders are willing to pay for the firm. ${ }^{11}$

\subsection{Negotiated versus competitive bid contracts}

Rule 50 of the Public Utilities Holding Company Act of 1935 requires registered public utility holding companies to sell securities through competitive bid, unless the firm obtains an exemption from the SEC. The Commission generally grants exemptions only if the firm cannot secure competitive bids or if it judges the market conditions to be 'unsettled'. Utilities not organized as holding companies are not affected by the Act.

Bhagat and Frost (1986) compare the issue costs for public utility firms that sell common stock using competitive bid and negotiated underwritten contracts. They measure total issue costs as the sum of underwriter's commissions, issuer-borne expenses and underpricing. They examine a sample of 552 offerings between 1973 and 1980 in which 73 are competitive bid and 479 are negotiated. Of the 479 negotiated offerings, 28 are negotiated after obtaining an exemption from the Securities and Exchange Commission. Bhagat and Frost estimate that the total issue costs are higher for firms which use negotiated offerings by 1.2 percent of the proceeds. Moreover, they find each

\footnotetext{
${ }^{10}$ The monitoring hypothesis for both investment bankers and independent auditing firms is also suggested by the evidence in Burton and Roberts (1967) and Carpenter and Strawser (1971) that a significant fraction of changes in auditing firms is associated with new securities offerings.

${ }^{11}$ The major observation that seems inconsistent with the monitoring explanation of the investment banker's function is the evidence that Smith (1977) and Bhagat (1983) provide. They examine firms that eliminate the preemptive right from the corporate charter. If investment bankers provide a valuable monitoring function, the benefit should be forecast and impounded when firms change policies. Thus, examination of returns around the elimination of the preemptive right (which requires firms to offer new shares first on a pro rata basis to existing shareholders) should pick up the present value of the incremental benefit from increased use of underwriters. But Bhagat finds a significant negative stock return at the proxy mailing date. Neither Bhagat nor Smith find significant returns at the annual meeting date when the vote is taken. There are two important qualifications of the evidence from preemptive right elimination. First, given the evidence in table 1 that the average response to new equity issues is negative. the negative effect observed by Bhagat could measure the higher probability of a stock offering. It is likely that firms only incur the expense to eliminate the preemptive right if they anticipate making an offering. Second, neither Smith nor Bhagat distinguish between firms who had used rights alone and firms that normally had their rights offerings underwritten. Neither the difference in monitoring nor out-of-pocket expenses are as great when comparing underwritten issues with underwritten rights offerings.
} 
component of cost (commissions, issuer-borne expenses and underpricing) higher in negotiated offerings.

The Bhagat and Frost evidence is consistent with that of Logue and Jarrow (1978), Ederington (1976) and Dyl and Joehnk (1976). Logue and Jarrow find that for a sample of 122 utility common stock issues between 1963 and 1974, the average underwriting commissions are 1.2 percent higher for negotiated offerings than competitive bid. Ederington examines 1081 issues of public utility and industrial bond offerings between 1964 and 1971. He finds that the offering yields on negotiated issues are approximately seven to eight basis points higher than the yields on equivalent competitive bid issues offered at the same time. And although underwriter spreads are on average less for competitive bid than negotiated issues, there are periods where negotiated bids are less expensive. Dyl and Joehnk examine a sample of 312 competitive bids and 71 negotiated new issues of debt by public utilities between 1972 and 1974 . They find that the average underwriters' commission as a fraction of proceeds is higher by 0.13 percent and the yield on the debt is higher by 36 basis points for negotiated than for competitive bid offers. These differences are evident across bond rating classes. Moreover, the results occur despite the fact that the average negotiated offer was approximately $\$ 10$ million larger than the average competitive bid; with economies of scale in the investment banking industry, larger issues are expected to receive lower percentage fees.

Thus, the evidence suggests that competitive bid offerings involve lower total flotation costs than negotiated offerings. Yet it appears that the major users of competitive bids are regulated firms which are required to do so. Firms not facing a regulatory constraint overwhelmingly choose negotiated offers.

Bhagat and Frost suggest that this behavior can be explained by differences in incentives between managers and shareholders and the costs of controlling the firm's managers. They conjecture that managers might benefit from: (1) side payments from investment bankers - especially those investment bankers who are members of the corporate board of directors, $(2)$ increased cc mpensation if managerial compensation is tied to accounting profits, ${ }^{12}$ and (3) less variation in cost (a benefit if the managers are risk-averse) since they offer evidence that the variance of issuing costs is higher for competitive bid offerings.

An alternative explanation follows from the hypothesis that there is information asymmetry between managers and outside securityholders that produces a derived demand for monitoring. In a competitive bid offering, the issuing firm specifies the details of the offering - the type of security, the issue date and (if it is a bond) the covenants. Thus, differential information available to managers can be used in setting the terms of the offering without constraints from

\footnotetext{
${ }^{12}$ Since future consulting services could be bundled into the underwriter's fee, and since costs of selling securities do not go through the income statement but are charged directly to the capital account, accounting earnings are higher though cash flows are lower.
} 
negotiation with investment bankers. And because the firm retains this additional flexibility, potential securityholders reduce the price they are willing to pay for the issue. Moreover, if it is difficult to control the use of information received by investment bankers not awarded the contract, then companies with potentially sensitive information are likely to find competitive bids costly. If the effective monitoring provided through a competitively bid offering is less than that provided through a negotiated underwritten issue, then firms would have incentives to employ negotiated offerings, even though the flotation costs are higher.

The monitoring hypothesis has implications for the cross-sectional distribution of competitive bid versus negotiated offerings. Firms with smaller information asymmetry between outside securityholders and managers will more likely use competitive bids. Thus, if the rate regulation process reduces the differential information, regulated utilities not subject to Rule 50 should use competitive bids more frequently than unregulated firms. Similarly, since competitive bids allow the issuing firm's management to specify the date of the offering, if the informational asymmetry problem is severe, competitive bids will be expensive. Thus, firms with less discretion in the timing of security offerings should more frequently employ competitive bids. Finally, with more senior claims, the informational asymmetry problem is less severe because the value of the claim is less sensitive to firm value. Thus straight debt, secured debt and non-convertible preferred stock should be sold through competitive bids more frequently than common stock, convertible preferred stock or convertible bonds.

However, Bhagat (1985) finds evidence which is consistent with this monitoring hypothesis. He examines the price reaction of firms affected by the suspension of Rule 50, which requires public utilities holding companies to seek competitive bids. He finds that at the announcement, share prices fall, and on reinstatement of the rule, share prices rise. Since the SEC suspends the rule when market conditions are 'unsettled', Bhagat's test may pick up adverse changes in underlying market conditions. However, that would require that the Commission either moves very fast or has valuable information about the state of the market otherwise unavailable to securityholders. Neither of these conditions seem plausible.

\subsection{Shelf versus traditional registration}

In March 1982, the SEC authorized Rule 415 on an experimental basis. It permitted certain firms to employ shelf registration for public security issues. Rule 415 was made permanent in November 1983. The procedure is called shelf registration because it allows companies to register securities, "put them on the shelf', and then issue the securities whenever they choose. It permits firms with more than $\$ 150$ million of stock held by investors unaffiliated with the company to specify and register the total dollar amount of securities they 
expect to sell publicly over the next two years. After the securities are registered, the firm can then offer and sell them for up to two years on a continuous basis. Rule 415 also allows the firm to modify a debt instrument and sell it without first filing an amendment to the registration statement. Thus, shelf registration allows qualifying firms additional flexibility both in structuring debt issues and in timing for all security issues.

The shelf registration procedure has been employed more frequently with debt than equity offerings. However, if the problem of differential information between managers and potential securityholders is severe, fewer equity issues should be registered through shelf procedures. With the additional timing flexibility given management, there is an increased opportunity to exploit inside information. Potential securityholders anticipating this problem would lower the amount they are willing to pay. Hence, stock price reactions to announcements of new equity offerings registered under Rule 415 should have more negative stock price reactions than if they were registered under traditional registration procedures.

Shelf registration procedures also should affect the structure of flotation costs. For example, shelf registration should lower fixed costs of public debt issues. This could lead qualified firms to change their practices with respect to debt offerings. Rather than use a line of credit at a bank until a large public issue can be made, firms could use the shelf registration process to place several smaller issues rather than having one large issue. Liquidity advantages with respect to secondary markets could be retained by having multiple issues with the same coupon rate, coupon dates, maturity dates and covenants.

Kidwell, Marr and Thompson (1984) and Rogowski and Sorensen (1985) examine the implications of allowing firms to choose between shelf and traditional registration procedures in issuing bonds. Both use regression techniques for a cross-section of issues to examine the alternative costs. They conclude that shelf registration lowers the interest rate by between 20 to 40 basis points.

\section{Initial public equity offerings}

Privately owned corporations face two major alternatives: to remain private or to become a public corporation. A public corporation incurs a number of obligations not imposed on private firms. ${ }^{13}$ For example, the SEC requires

\footnotetext{
${ }^{13}$ See DeAngelo, DeAngelo and Rice (1984). Fairly strict limits control the maximum number of equityholders a firm may have and still remain private. This limitation implies that the larger the firm, the greater the underdiversification cost imposed on the equityholders. The equity claims are also less liquid since some otherwise feasible transfers are restricted by regulation and would jeopardize the firm's private status. Note that since this constraint is on the ownership distribution of the firm, it generates a potential conflict among the stockholders of a private corporation. For example, if there can be no more than 20 equityholders to maintain private corporation status. but currently there are 15, a stockholder selling his shares to more than one person who is not currently a stockholder consumes degrees of freedom of the remaining equityholders.
} 
Table 5

Summary of estimated underpricing of new securities at issuance by type of offering. Underpricing is measured by the average percentage change from offer prices to after-market price.

\begin{tabular}{llrrr}
\hline & \multicolumn{1}{c}{ Study } & $\begin{array}{c}\text { Sample } \\
\text { period }\end{array}$ & $\begin{array}{c}\text { Sample } \\
\text { size }\end{array}$ & $\begin{array}{c}\text { Estimated } \\
\text { underpricing }\end{array}$ \\
\hline Initial public equity offering & Ibbotson (1974) & $1960-1969$ & 120 & $11.4 \%$ \\
Initial public equity offering & Ibbotson and Jaffe (1975) & $1960-1970$ & 2650 & 16.8 \\
Initial public equity offering & Ritter (1984) & $1960-1982$ & 5162 & 18.8 \\
& & $1977-1982$ & 1028 & 26.5 \\
& & $1980-1981$ & 325 & 48.4 \\
Initial public equity offering & Ritter (1985) & $1977-1982$ & & \\
$\quad$ firm commitment & & & 664 & 14.8 \\
$\quad$ best efforts & Chalk and Peavy (1985) & $1974-1982$ & 364 & 47.8 \\
Initial public equity offering & & & 415 & 13.8 \\
$\quad$ firm commitment & & 82 & 52.0 \\
$\quad$ best efforts & Schipper and Smith (1986) & $1963-1983$ & 36 & 0.19 \\
Equity carve-outs & Smith (1977) & $1971-1975$ & 328 & 0.6 \\
Seasoned new equity offering & & $1973-1980$ & 552 & -0.30 \\
Seasoned new utility equity offering & Bhagat and Frost (1986) & $1973-19$ \\
$\quad$ negotiated & & & 479 & -0.25 \\
$\quad$ compctitivc bid & & $1962-1974$ & 412 & -0.65 \\
Primary debt issue & Weinstein (1978) & & 0.05 \\
\hline
\end{tabular}

periodic filings which can be costly in three dimensions: (1) the out-of-pocket production costs, (2) the value of management's time, and (3) the reduction in firm value from disclosing valuable information otherwise unavailable to the firm's competitors.

Private firms that choose to go public typically obtain the services of an underwriter and have an initial public equity offering. Initial public equity offerings are an interesting special case of security offerings. They differ from offerings previously discussed in two important ways: (1) The uncertainty about the market clearing price of the offering is significantly greater than for public corporations with claims currently trading. (2) Because the firm has no traded shares, examination of stock price reactions to announcements (as in section 2) are impossible. The first difference affects the way these securities are marketed; the second limits the ways researchers can study the offerings.

\subsection{Underpricing}

Examination of the return behavior of initial public equity offerings from offer price to after-market indicates that the average issue is offered at a significant discount from the price expected in the after-market; however, after-market returns appear to be normal [Ibbotson (1975), Ibbotson and Jaffe (1975), Ritter $(1984,1985)$ and Chalk and Peavy (1985)]. Table 5 summarizes the results from studies of offer prices for initial public cquity offerings as well 
as new issues of seasoned equity and bonds. For initial public equity offerings, the average underpricing appears to exceed 15 percent.

Hypotheses have been offered to explain underpricing of new issues [Baron (1982), Ritter (1985), Chalk and Peavy (1985), Rock (1986) and Beatty and Ritter (1986)]. Baron focuses on the asymmetry in information between the issuing firm and the investment banker. The other authors focus on the asymmetry of information between informed and uninformed potential securityholders.

The Rock and the Ritter analyses of underpricing assume that markets are efficient in a very specific sense - that the marginal investment in information yields a normal expected return. Potential securityholders can be divided into three groups: (1) marginal investors who are indifferent about investing in information, (2) inframarginal investors who are better informed and thus earn abnormal returns, and (3) inframarginal investors who rationally choose (either because of the size of their portfolio or the opportunity cost of their time) not to invest in information.

In an offering, there is uncertainty about the market-clearing price. If the offer prices are set at their expected market-clearing price, uninformed investors systematically earn below normal returns; if an issue is underpriced, informed investors also submit bids and the issue is rationed; and if the issue is overpriced, informed investors are less likely to submit bids and the issue is more likely to be undersubscribed. Hence, uninformed investors systematically receive more of overpriced issues and less of underpriced issues. Uninformed investors anticipate this adverse selection and bid only if the offer price is below their expected after-market price by enough to compensate for their expected losses on overpriced issues. This implies that the average underpricing is greater for issues with greater price uncertainty.

Baron (1982) analyzes an optimal contract for advising and marketing services between a firm and its investment banker. He hypothesizes that the investment banker is better informed about the market demand for the firm's securities than is the firm. Since the firm must compensate the investment banker for providing advice in setting the offer price for the issue and for marketing the securities, the optimal offer price is a decreasing function of the uncertainty about the market demand for the issue, while the value of delegation to the underwriter is an increasing function of the uncertainty.

Thus, while the alternative hypotheses focus on different information problems - (1) between informed and uninformed potential securityholders and (2) between the issuing firm and its investment banker - the two yield similar implications about which firms employ which contract for a given issue.

Beatty and Ritter (1986) attempt to test the underpricing hypotheses using data from initial public offerings. They argue that there is an equilibrium amount of underpricing. If an investment banker underprices too much, given the characteristics of the issue, the investment banker loses future offerings. If 
the investment banker underprices too little, he loses investors. Beatty and Ritter estimate an underpricing function and examine the average deviation of 49 investment bankers who handled four or more initial public offerings during the period 1977-1981. They compare subsequent performance of the 24 underwriters whose average deviation from their estimated normal underpricing is greatest with that of the remaining 25 underwriters whose average deviation is least. For the 24 with the greatest deviation, their market share goes from 46.6 to 24.5 percent and five of the 24 cease operations during 1981-1982. For the 25 with the smallest deviation, their market share goes from 27.2 to 21.0 percent and one of the 25 ceases operation.

Schipper and Smith find that for their sample of initial public offerings, which result from equity carve-outs, the average underpricing is only 0.19 percent. It seems plausible that potential asymmetric information problems are less severe for this subset of initial offerings than the average; thus, less underpricing is expected. Yet it is surprising that the measured underpricing is so similar to that of seasoned new issues. ${ }^{14}$

As table 5 shows, security issues by public corporations are also underpriced. Smith finds seasoned new equity issues underpriced by 0.6 percent, Bhagat and Frost find seasoned equity issues by utilities overpriced by 0.3 percent, and Weinstein finds new bonds underpriced by 0.05 percent. Parsons and Raviv (1985) extend Rock's analysis of underpricing initial public equity offerings to consider seasoned new equity offerings. In a seasoned offering, potential security holders have the option of buying after the announcement but before the offering, at the offering or in the after-market. Again, the asymmetry in information among investors implies that the offer price will be set systematically below both the security price between the announcement and the offer date as well as below the expected after-market price. ${ }^{15}$ This hypothesis implies that underpricing should be greater with competitive bid than negotiated offerings, and with shelf than traditional registration procedures. (Unfortunately, this implication for shelf issues is somewhat more difficult to test because of the proximity of the announcement and issue dates.)

Smith and Chalk and Peavy indicate that the average measured underpricing could overstate the cost imposed on issuers if the underwriter can extract gains

\footnotetext{
${ }^{14}$ This underpricing evidence combined with the clustering of event dates provides potential corroboration of the Ibbotson and Jaffee (1975) and Ritter (1984) hypotheses about the non-stationary time series behavior of underpricing.

${ }^{15}$ Note that the Bhagat and Frost evidence is potentially consistent with the Parsons and Raviv hypothesis if one recognizes the difference in transactions costs in the two transactions. The transaction generating the closing price will as frequently be initiated by a buy order as a sell order; on average, the closing price represents the midpoint of the bid-ask spread. Moreover, the transaction generating the closing price involves brokerage fees. There are no purchaser-borne fees in a primary distribution. Phillips and Smith (1980) estimate the bid-ask spread at 0.6 percent and the brokerage fees for individuals at 0.4 percent. Thus, the purchaser's expenditure is the closing price plus half the bid-ask spread plus the brokerage fee. These adjustments exceed Bhagat and Frost's measured overpricing.
} 
by rationing ex post underpriced issues. Then, competition among underwriters transfers the expected gains back to the issuer through the quoted offer fees.

\subsection{Best efforts versus firm commitment contracts}

Two alternative forms of underwriting contracts are typically employed in initial public equity offerings. The first is a firm commitment underwriting agrecment under which the underwriter agrees to purchase the whole issue from the firm at a particular price for resale to the public. The second is a best efforts underwriting agreement under which the underwriter acts only as a marketing agent for the firm. ${ }^{16}$ The underwriter does not agree to purchase the issue at a predetermined price, but sells the security and takes a predetermined spread, with the firm taking the residual. The agreement generally specifies a minimum amount that must be sold within a given period of time; if this amount is not reached, the offering is cancelled. Ritter (1985) reports that 35 percent of initial public equity offerings from 1977-1982 are sold with best efforts contracts, although they represent only 13 percent of the gross proceeds.

The information problem between informed and uninformed potential security holders, as well as the information and contracting problems between the issuing firm and its investment banker, influence the choice between firm commitment and best efforts contracts. Ritter (1985) contrasts the preceding argument for underpricing firm commiments with the incentives in a best efforts contract. He argues that in a best efforts contract, if the issue is overpriced and the issue sales fall short of the minimum specified in the underwriting contract, the offer is cancelled and the losses to uninformed investors are reduced. Structuring the contract in this manner reduces the problem faced by uninformed potential securityholders, and thus reduces the discount necessary to induce them to bid.

Ritter argues that the relative attractiveness of the two contracts varies with changes in the amount of uncertainty associated with the issue. The prohibition against raising prices for an oversubscribed issue imposed by the Rules of Fair Practice of the National Association of Security Dealers is analogous to the firm giving a call option to potential stockholders [sce Smith (1979)]. Thus, in a firm commitment offering, the expected proceeds to the firm are reduced if the uncertainty about after-market prices is higher. In a best efforts contract, the firm again gives the call because of the rule against raising the price, but the firm also gives an option to potential shareholders to put the shares back to the firm if the issue is undersubscribed. Thus, with more uncertainty about after-market prices, best efforts contracts become relatively more attractive.

\footnotetext{
${ }^{16}$ Booth and Smith (1986) report that in non-initial offerings from 1977 1982, best efforts contracts are used in two percent of the equity offerings, two percent of convertible issues, no preferred stock issues, and eight percent of debt issues.
} 
Mandelker and Raviv (1977), Baron (1979, 1982) and Baron and Holmstrom (1980) hypothesize that there is uncertainty among the capital market participants about the market-clearing price for the securities. Furthermore, their models focus on the conflict of interest between the issuing firm and its underwriter. They derive optimal contracts, either best efforts or firm commitment, based on the uncertainty associated with the issue and the degree of risk aversion of the issuer and investment banker. Mandelker and Raviv assume symmetric information when the contract is negotiated between the firm and the investment banker. Baron (1979) also assumes symmetric information between the investment banker and the issuing firm but considers the potential conflict of interest because of the issuer's inability to observe the investment banker's marketing effort. Baron and Holmstrom assume symmetric information at the time of contracting but allow the investment banker to acquire information during the pre-selling period before the offering. Baron (1982) allows the investment banker to have better information about the market at the time the contract is negotiated. In their analyses a firm commitment offering is more likely to be optimal: (1) the more risk-averse the issuer, (2) the less risk-averse the investment banker, (3) the less the uncertainty about the market clearing security price, (4) the less the asymmetry in information between the issuer and the investment banker, and (5) the more observable the investment banker's effort.

Therefore, both lines of analysis predict that best efforts contracts are more likely the greater the uncertainty of the after-market issue price. Ritter tests this hypothesis using the after-market standard deviation of returns as a proxy for ex ante uncertainty. He estimates the after-market standard deviation using the first 20 quoted bid prices after the offering. He finds that the average standard deviation for 285 best efforts offerings is 7.6 percent, and is statistically significantly above the 4.2 percent standard deviation of 641 firm commitment offerings. This is consistent with the hypothesis that issues with greater uncertainty are more likely to employ best efforts than firm commitment contracts.

\section{Unresolved issues}

The growth of knowledge about the process of raising capital has been substantial. I believe that this area will continue to receive a great deal of attention, particularly because a number of interesting questions have been suggested by this examination of the capital acquisition process: (1) Do stock price reactions to announcements of new security sales differ between rights and underwritten offers? (2) Marsh (1979) reports that in 1975, 99 percent of the new equity in England was raised through rights offers. Why is there the dramatic difference in use of rights between the United States and the United Kingdom? (3) Researchers typically have contrasted underwritten offers with 
non-underwritten rights offers, yet in a significant fraction of rights offers, underwriters are retained on a standby basis. Under what circumstances are rights offerings with standby underwriting contracts optimal? (4) Standby underwriting contracts typically are either single-fee agreements or two-fee agreements which specify both a 'standby fee' and a 'take-up fee' based on the number of rights handled. What determines the optimal fee structure? (5) Underwriters typically trade in the secondary market during and immediately after a security offering. Why is this 'stabilization' activity beneficial? (6) Underwritten equity offers frequently include a 'green shoe' option which gives the underwriter the right to buy additional shares from the firm at the offer price. For which offers is that provision optimal? (7) If we restrict ourselves to companies not constrained by Rule 50 of the Public Utilities Holding Company Act, how does frequency of use of competitive bids vary with the type of security? With the size of the offering? With the industry of the issuing firm? And with the ownership concentration of the firm? (8) Are convertible bonds and convertible preferred stock underpriced at issue? (9) Are there differences in underpricing between issues registered under Rule 415 versus traditional procedures?

\section{References}

Ahrony, Joseph and Itzhak Swary, 1980, Quarterly dividend and earnings announcements and stockholder's returns: An empricial analysis, Journal of Finance 35, 1-12.

Alexander, Gordon J., P. George Benson and Joan M. Kampmeyer, 1984, Investigating the valuation effects of announcements of voluntary corporate selloffs, Journal of Finance 39. $503-517$

Asquith, Paul, 1983, Merger bids, uncertainty, and stockholder returns, Journal of Financial Economics 11, 51-83.

Asquith. Paul and David Mullins, 1983. The impact of initiating dividend payments on shareholder wealth, Journal of Business 56, 77-96.

Asquith, Paul and David Mullins, 1986, Equity issues and offering dilution, Journal of Financial Economics, this issue.

Baron. David P., 1979, The incentive problem and the design of investment banking contracts, Journal of Banking and Finance 3, 157-175

Baron, David P., 1982, A model of the demand for investment banking advising and distribution services for new issues, Journal of Finance 37, 955-976.

Baron, David P. and Bengt Holmstrom, 1980, The investment banking contract for new issues under asymmetric information: Delegation and the incentive problem, Journal of Finance 35 , $1115-1138$.

Beatty, Randolph P. and Jay R. Ritter, 1986, Investment banking, reputation, and the underpricing of initial public offerings, Journal of Financial Economics, this issue.

Bhagat, Sanjai, 1983, The effect of pre-emptive right amendments on shareholder wealth, Journal of Financial Economics 12, 289-310.

Bhagat, Sanjai, 1985, The effect of management's choice between negotiated and competitive cquity offerings on shareholder wealth, Journal of Financial and Quantitative Analysis, forthcoming.

Bhagat, Sanjai and Peter A. Frost, 1986, Issuing costs to existing shareholders in competitive and negotiated underwritten public utility equity offerings, Journal of Financial Economics, this issue. 
Booth, James R. and Richard L. Smith, III, 1986, Capital raising, underwriting and the certification hypothesis, Journal of Financial Economics, this issue.

Bradley, Michael, Anand Desai and E. Han Kim, 1983, The rationale behind interfirm tender offers: Information or synergy?, Journal of Financial Economics 11, 183-206.

Bradley, Michael and L. M. Wakeman, 1983, The wealth effects of targeted share repurchases, Journal of Financial Economics 11, 301-328.

Brennan, Michael and Eduardo Schwartz, 1978, Corporate income taxes, valuation, and the problem of optimal capital structure, Journal of Business 51, 103-114.

Brickley, James, 1983, Shareholder wealth, information signaling and the specially designated dividend: An empirical study, Journal of Financial Economics 12, 187-209.

Burton, John C. and William Roberts, 1967, A study of auditor changes, Journal of Accountancy, $31-36$.

Carpenter, Charles G. and Robert H. Strawser, 1971, Displacement of auditors when clients go public, Journal of Accountancy, 55-58.

Chalk, Andrew J. and John W. Peavy, III, 1985, Understanding the pricing of initial public offerings, Unpublished manuscript (Southern Methodist University, Dallas, TX).

Charest, Guy, 1978, Dividend information, stock returns, and market efficiency - II, Journal of Financial Economics 6, 297-330.

Dann, Larry, 1980, The effect of common stock repurchase on stockholder returns, Unpublished dissertation (University of California, Los Angeles, CA).

Dann, Larry, 1981, Common stock repurchases: An analysis of returns to bondholders and stockholders, Journal of Financial Economics 9, 113-138.

Dann, Larry and Harry DeAngelo, 1983, Standstill agreements, privately negotiated stock repurchases and the market for corporate control, Journal of Financial Economics 11, 275-300.

Dann, Larry Y., David Mayers and Robert J. Raab, Jr., 1977, Trading rules, large blocks and the speed of price adjustment, Journal of Financial Economics 4, 3-22.

Dann, Larry $Y$. and Wayne H. Mikkelson, 1984, Convertible debt issuance, capital structure change and financing-related information: Some new evidence, Journal of Financial Economics $13,157-186$.

Dealers' Digest Inc., 1985, Five year directory of corporate financing 1980-1984, Anthony V. Ricotta, ed. (Mason Slaine, New York).

DeAngelo, Harry, Linda DeAngelo and Edward M. Rice, 1984, Going private: Minority freezeouts and shareholder wealth, Journal of Law and Economics 27, 367-401.

DeAngelo, Harry and Ronald Masulis, 1980, Optimal capital structure under corporate and personal taxation, Journal of Financial Economics 8, 3-29.

DeAngelo, Linda, 1981, Auditor independence, 'low balling', and disclosure regulation, Journal of Accounting and Economics 3, 113-127.

Dietrich, J. Richard, 1984, Effects of early bond refundings: An empirical investigation of security returns, Journal of Accounting and Economics 6, 67-96.

Dodd, Peter, 1980, Merger proposals, management discretion and stockholder wealth, Journal of Financial Economics 8, 105-138.

Dodd, Peter and Richard S. Ruback, 1977, Tender offers and stockholder returns: An empirical analysis, Journal of Financial Economics 5, 351-374.

Dodd, Peter and Jerold B. Warner, 1983, On corporate governance: A study of proxy contests, Journal of Financial Economics 11, 401-438.

Dyl. Edward A. and Michael D. Joehnk, 1976, Competitive versus negotiated underwriting of public utility debt, Bell Journal of Economics 7, 680-689.

Easterbrook, Frank H., 1983, Two agency-cost explanations of dividends, American Economic Review 74, 650-659.

Eckbo, B. Espen, 1983, Horizontal mergers, collusion, and stockholder wealth, Journal of Financial Economics 11, 241-273

Eckbo, B. Espen, 1986, Valuation effects of corporate debt offerings, Journal of Financial Economics, this issue.

Ederington. Louis H., 1976, Negotiated versus competitive underwritings of corporate bonds, Journal of Finance $31,17-28$.

Fama, Eugene F., 1978, The effect of a firm's investment and financing decisions, American Economic Review 68, 272-284. 
Fama, Eugene F., 1980, Agency problems and the theory of the firm, Journal of Political Economy $88,288-307$.

Fama, Eugene F. and Michael C. Jensen, 1985, Residual claims and investment decisions, Journal of Financial Economics 14, 101-119.

Gilson, Ronald J. and Reinier H. Kraakman, 1984, The mechanisms of market efficiency, Virginia Law Review 70, 549-644.

Hansen, Robert S. and John M. Pinkerton, 1982, Direct equity financing: A resolution of a paradox, Journal of Finance 37, 651-665.

Heinkel, Robert and Eduardo S. Schwartz, 1984, Rights versus underwritten oflerings: An asymmetric information approach, Unpublished manuscript (University of British Columbia, Vancouver).

Hite, Gailen L. and James E. Owers, 1983, Security price reactions around corporate spin-off announcements, Journal of Financial Economics 12, 409-436.

Hite, Gailen L. and James E. Owers, 1985, Sale divestitures: Implications for buyers and sellers, Unpublished manuscript (Southern Methodist University, Dallas, TX).

Holderness, Clifford G. and Dennis P. Sheehan, 1985, Raiders or saviors? The evidence on six controversial investors, Journal of Financial Economics 14, 555-579.

Ibbotson, Roger, 1975, Price performance of common stock new issues, Journal of Financial Economics 2, 235-272.

Ibbotson, Roger G. and Jeffrey F. Jaffe, 1975, 'Hot issue' markets, Journal of Finance 30 , 1027-1042.

Jain, Prem C., 1985, The effect of voluntary sell-off announcements on shareholder wealth, Journal of Finance 40, 209-224.

Jensen, Michael $\mathrm{C}$. and William H. Meckling, 19/6, Theory of the firm: Managerial behavior agency costs and ownership structure, Journal of Financial Economics 3, 305-360.

Jensen, Michael C. and Richard S. Ruback, 1983, The market for corporate control: The scientific evidence, Journal of Financial Economics 11, 5-50.

Kidwell, David S., M. Wayne Marr and G. Rodney Thompson, 1984, SEC Rule 415: The ultimate competitive bid, Journal of Financial and Quantitative Analysis 19, 183-195.

Kim, E. Han and John D. Schatzberg, 1985, Voluntary liquidation and stockholder returns, Unpublished manuscript (University of Michigan, Ann Arbor, MI)

Klein, April, 1984, The effects of voluntary corporate divestitures on shareholders' wealth, Unpublished manuscript (University of Chicago, Chicago, IL).

Kolodny, Richard and Diane Rizzuto Suhler, 1985, Changes in capital structure, new equity issues, and scale effects, Journal of Financial Research 8, 127-136.

Kraus, Alan and Robert Litzenberger, 1973, A state preference model of optimal financial leverage, Journal of Finance 28, 911-922.

Linn, Scott and J. Michael Pinegar, 1985, The effect of issuing preferred stock on common stockholder wealth, Unpublished manuscript (University of Iowa, Iowa City, IA).

Logue, Dennis E. and Robert A. Jarrow, 1978, Negotiation vs, competitive bidding in the sale of securities by public utilities, Financial Management 7, 31-39.

Mandelker, Gershon and Artur Raviv, 1977. Investment banking: An economic analysis of optimal underwriting contracts, Journal of Finance 32, 683-694.

Marsh, Paul, 1979, Equity rights issues and the efficiency of the UK stock market, Journal of Finance $34,839-862$.

Marsh, Paul, 1982, The choice between equity and debt: An empirical study, Joumal of Finance $37,121-144$.

Masulis, Ronald M., 1980, Stock repurchase by tender offer: An analysis of the causes of common stock price changes, Journal of Finance 35, 305-319.

Masulis, Ronald, 1983, The impact of capital structure change on firm value: Some estimates, Journal of Finance 38, 107-126.

Masulis, Ronald, 1985, Changes in ownership structure: Conversions of mutual savings and loans to stock charter. Unpublished manuscript (University of California. Los Angeles, CA).

Masulis, Ronald W. and Ashok Korwar, 1986. Seasoned equity offerings: An empirical investigation, Journal of Financial Economics, this issue.

Mayers, David and Clifford Smith, 1982, On the corporate demand for insurance, Journal of Business 55, 281-296. 
Mayers, David and Clifford Smith, 1985, Ownership structure and control: The mutualization of stock life insurance companies, Journal of Financial Economics, forthcoming.

McConnell, John and Chris J. Muscarella, 1985, Corporate capital expenditure decisions and the market value of the firm, Journal of Financial Economics 14, 399-422.

McConnell, John and Timothy Nantell, 1985, Corporate combinations and common stock returns: The case of joint ventures, Journal of Finance 40, 519-536.

McConnell, John and Gary Schlarbaum, 1981, Evidence on the impact of exchange offers on security prices: The case of income bonds, Journal of Business 54, 65-85.

Mikkelson, Wayne, 1981, Convertible calls and security returns, Journal of Financial Economics 9 , 237-264.

Mikkelson, Wayne H. and M. Megan Partch, 1985, Stock price effects and costs of secondary distributions, Journal of Financial Economics 14, 165-194.

Mikkelson, Wayne H. and M. Megan Partch, 1986, Valuation effects of security offerings and the issuance process, Journal of Financial Economics, this issue.

Mikkelson, Wayne H. and Richard S. Ruback, 1985, Corporate investments in common stock, Journal of Financial Economics, forthcoming.

Miles, J. and J. Rosenfeld, 1983, A empirical analysis of the effects of spin-off announcements on shareholder wealth, Journal of Finance 38, 1597-1606.

Miller, Merton, 1977, Debt and taxes, Journal of Finance 32, 26l-276.

Miller, Merton and Kevin Rock, 1985, Dividend policy under asymmetric information, Journal of Finance, forthcoming.

Modigliani, Franco and Merton Miller, 1958, The cost of capital, corporation finance and the theory of investment, American Economic Review 48, 261-297.

Modigliani, Franco and Merton Miller, 1963, Corporate income taxes and the cost of capital: A correction, American Economic Review 53, 433-443.

Myers, Stewart, 1977, Determinants of corporate borrowing, Journal of Financial Economics 5 , 147-175.

Myers, Stewart, 1984, The capital structure puzzle, Journal of Finance 39, 575-592.

Myers, Stewart C. and Nicholas S. Majluf, 1984, Corporate financing and investment decisions when firms have information that investors do not have, Journal of Financial Economics 13 , $187-221$.

Parsons, John and Artur Raviv, 1985, Underpricing of seasoned issues, Journal of Financial Economics 14, 377-397.

Pettway, Richard H. and Robert C. Radcliffe, 1985, Impacts of new equity sales upon electric utility share prices, Financial Management 14, 16-25.

Phillips, Susan M. and Clifford W. Smith, Jr, 1980, Trading costs for listed options: The implications for market efficiency, Journal of Financial Economics 8, 179-201.

Ritter, Jay R., 1984, The 'hot issue' market of 1980, Journal of Business 57, 215-240.

Ritter, Jay R., 1985, The choice between firm commitment and best effort contracts, Unpublished manuscript (University of Pennsylvania, Philadelphia, PA).

Rock, Kevin, 1985, Why new issues are underpriced, Journal of Financial Economics, this issue.

Rogowski, Robert J. and Eric H. Sorensen, 1985, Deregulation in investment banking: Shelf registrations, structure, and performance, Financial Management 14, 5-15.

Rosenfeld, Ahron, 1982, Repurchase offers: Information adjusted premiums and shareholders' response, MERC monograph series MT-82-01 (University of Rochester, Rochester, NY).

Rosenfeld, James D., 1984, Additional evidence on the relation between divestiture announcements and shareholder wealth, Journal of Finance 39, 1437-1448.

Rozeff, Michael S., 1982, Growth, beta and agency costs as determinants of dividend payout ratios, Journal of Financial Research 5, 249-259.

Schneller, Meir 1., 1984, Dividend policy and the stockholders-management contlict, Unpublished manuscript (University of Pennsylvania, Philadelphia, PA).

Schipper, Katherine and Abbie Smith, 1983, Effects of recontracting on shareholder wealth: The case of voluntary spin-offs, Journal of Financial Economics 12, 437-467.

Schipper, Katherine and Abbie Smith, 1986, A comparison of equity carve-outs and seasoned equity offerings: Share price effects and corporate restructuring, Journal of Financial Economics, this issue.

Scholes, Myron, 1972, Market for securities: Substitution versus price pressure and the effects of information on share prices, Journal of Business 45, 179-211 
Smith, Clifford, 1977, Alternative methods for raising capital: Rights versus underwritten offerings, Journal of Financial Economics 5, 273-307.

Smith, Clifford, 1979, Applications of option pricing analysis, in: J. L. Bicksler, ed., Handbook of financial economics (North-Holland, Amsterdam) 80-121.

Smith, Clifford and Jerold Warner, 1979, On financial contracting: An analysis of bond covenants, Journal of Financial Economics 7, 117-161.

Smith, Clifford and Ross Watts, 1982, Incentive and tax effects of U.S. executive compensation plans, Australian Journal of Management 7, 139-157.

Smith, Clifford and Ross Watts, 1984, The structure of executive compensation contracts and the control of management, Unpublished manuscript (University of Rochester, Rochester, NY).

Smith, Richard L. and Manjeet Dhatt, 1984, Direct equity financing: A resolution of a paradox: A comment, Journal of Finance 39, 1615-1618.

Stulz, Rene M. and Herb Johnson, 1985, An analysis of secured debt, Journal of Financial Economics 14, 501-521.

Vermaelen, Theo, 1981, Common stock repurchases and market signalling, Journal of Financial Fconomics 9, 139-183.

Vetsuypens, Michel, 1985, Agency costs, asset substitution, and voluntary corporate divestitures: A test of bondholder wealth expropriation, Unpublished manuscript (University of Rochester, Rochester, NY).

$\mathrm{Vu}$, Joseph D., 1986, An examination of corporate call behavior on nonconvertible bonds, Journal of Financial Economics, forthcoming.

Wakeman, Lee M., 1981, The real function of bond rating agencies, Chase Financial Quarterly 1, $18-26$.

Watts, Ross L., 1977, Corporate financial statements, a product of the market and political processes, Australian Journal of Management 2, 53-75.

Weinstein, Mark, 1978, The seasoning process of new corporate bond issues, Journal of Finance $33,1343-1354$. 